\title{
DEVELOPMENT OF THE JEWISH URBAN SETTLEMENT \\ IN ISRAEL IN VIEW OF THE THEORY \\ OF THE INNOVATION DIFFUSION
}

\begin{abstract}
Presentation of the current state and development tendencies of Jewish urban settlement in Israel against the innovation diffusion theory.

Analysis of the growth tempo of the number of cities in Israel allows to claim that urban Jewish settlement network develops in accordance with the innovation diffusion model.

Assuming that the theory fits the urban settlement development pattern on the surveyed territories, the directions taken by the impulses sent by innovation sources have been determined based on the corridor settlement development theory.

The hypothesis has been verified against the factors influencing spatial development directions of the Jewish urban settlement using a dynamic (synchronic-comparative) diffusion process simulation model, built with the Monte Carlo method.

The conducted analyses and procedures verifying the model distribution of Jewish settlement in Israeli cities in 1948, 1967 and 1992 allowed to conclude that the highest stochastic concordance between the model accounting for the innovation diffusion theory elements, and the real distribution of Jewish settlement cities holds for 1948 and 1967. According to the diffusion innovation theory, these years correspond to the colonisation stage. The model diversifies from reality for late 1967, when network densification process was coming to an end and city competition stage was starting.

Despite statistical validity of the hypotheses, the results show that besides the analysed factors influencing the development of Jewish urban settlement, other variables, not accounted for in the model, are also significantly influential.
\end{abstract}

Key words: Jewish urban settlement, theory of innovation diffusion.

The formation of the Israel society is to a large extent shaped by the still lasting influx of Jewish people from all continents.

Intensive settlement processes began at the end of the $19^{\text {th }}$ century. Fast increase of the number of inhabitants, intensive economic development and a long tradition of urban life caused a dynamic development of the urban network of settlement.

Due to a continual influx of Jewish people (Table 1), the population of Israel grew very fast: from 1.9 million in 1948 to 6.7 million in 2003 (District, subdistricts and natural regions, Jerusalem, 1993; CBS, Jerusalem, 2003, http://www.cbs.gov.il/population/new2003).

In $200291.7 \%$ of the population lived in cities (CBS, Jerusalem, 2003, http://www.cbs.gov.il/population/new2003/). The most urbanised districts were 


\begin{tabular}{|c|c|}
\hline Years & $\begin{array}{c}\text { Number of immigrants } \\
\text { in thousands }\end{array}$ \\
\hline $1948-1951$ & 688 \\
$1952-1959$ & 272 \\
$1960-1969$ & 374 \\
$1970-1979$ & 346 \\
$1980-1989$ & 154 \\
$1990-1995$ & 687 \\
$1996-2002$ & 357 \\
\hline
\end{tabular}

Source: Israel Statistical, 1995; CBS, Jerusalem, 2003, http://www.cbs.gov.il/population/new2003/.

those of Tel-Aviv (99.55\%) and of Jerusalem (96.02\%). The lowest urbanisation index occurred in the district of Nazareth, where Arabs constitute 45.08\% of population, whose main occupations are, among others, cultivation of olives, wheat and tobacco, which is facilitated by fertile soils and favourable climate with adequate precipitation.

The cities and towns were classified, in accordance with the Central Bureau of Statistics, into eight classes depending on the population size (Table 2). Small units, with population from 2 to 9.9 thousand, constitute the largest number of towns, both Jewish and Arab. In the case of the Jewish settlement, however, only $5.1 \%$ or urban population lives in such small towns and $6.4 \%$ lives in towns of 10 to 19.9 thousand inhabitants. The largest fraction of the population lives in large cities, with population from 100 to 200 thousand $-30.2 \%$ and in the four largest cities, with more than 200 thousand inhabitants (Jerusalem, Tel Aviv - Jaffa, Haifa, Rishon-Le-Zion) - 28.3\%. Among Arab cities there is only one town with more than 50 thousand inhabitants (Nazareth); 43.67\% of Arab urban population lives in towns of 2 to 9.9 thousand inhabitants and $30.7 \%$ in towns of 10 to 19.9 thousand inhabitants.

Around $60 \%$ of Jewish urban population of Israel is concentrated in 14 large cities (above 100 thousand inhabitants). The Arab population, on the other hand, lives mostly in small towns of fewer than 10 thousand inhabitants.

The current state of the Jewish urban settlement is the result of a longlasting process. Its beginnings are linked with the cities known since the antiquity, such as Nazareth or Akka. Many cities have developed from rural centres: e. g., Rehoboth, Hadera or Petah-Tiqva. Until 1909 in the region under investigation only 18 urban units of Jewish settlement existed; they were localised mostly along the coastal plains (Fig. 1). Fertile soils, not lacking moisture, occur there next to sandy coasts. Other factors favouring set- 
Table 2.

Number of cities in Israel by size classes

\begin{tabular}{|c|c|}
\hline $\begin{array}{c}\text { Size classes } \\
\text { (in thousands of inhabitants) }\end{array}$ & Number of cities \\
\hline $2-9,9$ & 113 \\
$10-19,9$ & 39 \\
$20-49,9$ & 45 \\
$50-99,9$ & 9 \\
$100-199,9$ & 10 \\
$200-299,9$ & 2 \\
$300-399,9$ & 1 \\
Over 400 & 1 \\
\hline
\end{tabular}

Source: Based on data: List of Localities, Their Population and Codes, Jerusalem, 1993, CBS, Jerusalem, 2003, http://www.cbs.gov.il/population/new2003/

tlements were surface relief and the proximity of the sea, which facilitated trade. Four settlements were founded in upper Galilee, regarded as the most advantageous region for settlement because of its soil and climate conditions. In that region, however, Arab population dominated.

By the year 193119 more cities came into existence (Table 3, Fig. 2). Cities in upper Galilee lost their importance. The largest number of cities were established in 1914-1928 (Table 3), during the third and fourth aliyah (literally: ascension, going up - the name of large waves of Jewish immigrants returning to the area of Israel) when Palestine remained under the British mandate. In 1909, north of the ancient Jaffa, Jewish settlers founded the first modern Jewish city: Tel Aviv. Cities were developing mostly along the coastal plains. Three cities were founded at the foot of Mount Carmel in the fertile valley of Jezreel.

By the year 1948 as many as 22 cities had been established (Table 3, Fig. 3). Most of them, as in the previous period, were localised on the coastal plains and in the strip running from Bay Haifa along the Jezreel valley. Furthermore, thanks to trade, the city of Beer Sheba began to dynamically develop on the boundary of the Negev desert.

An intense development of Jewish urban settlement continued in the years 1948 through 1961 and the number of cities grew by 29 (Table 3, Fig. 4). Traditionally, cities were founded in the two zones mentioned above. Furthermore, cities in upper Galilee resumed their development. Territorial settlement of the Negev desert, a region disadvantageous for humans, began also at that time. The importance of Eilat, a harbour town on Bay Akabam grew quickly. New cities in Galilee and in the Negev Desert were founded as a result of the governmental policy aiming at the unburdening of the existing cities. To attract immigrants, textile, clothing factories and industrial works were built in new cities (Gradus, Stern, 1980). 


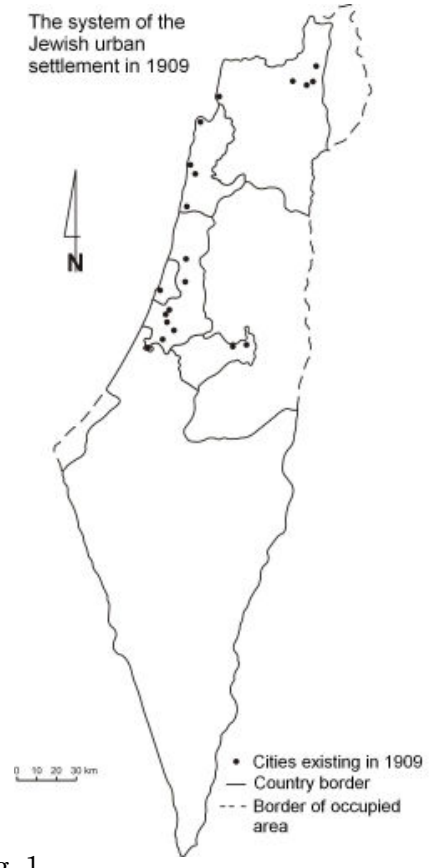

Fig. 1.

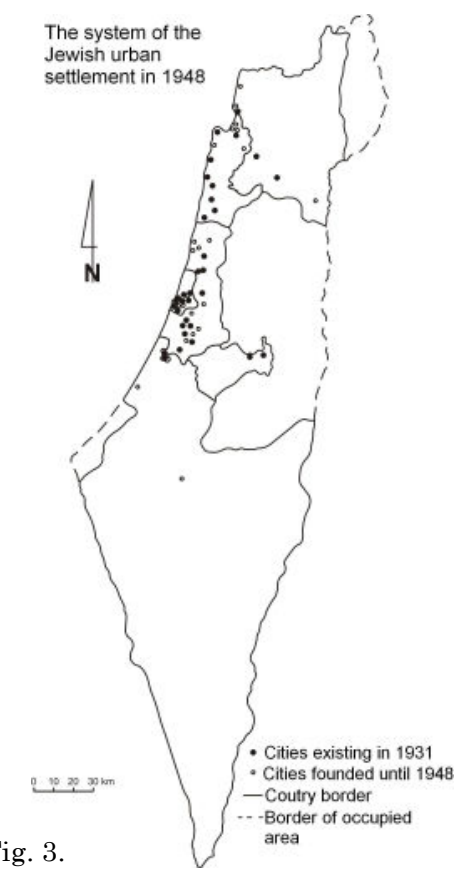

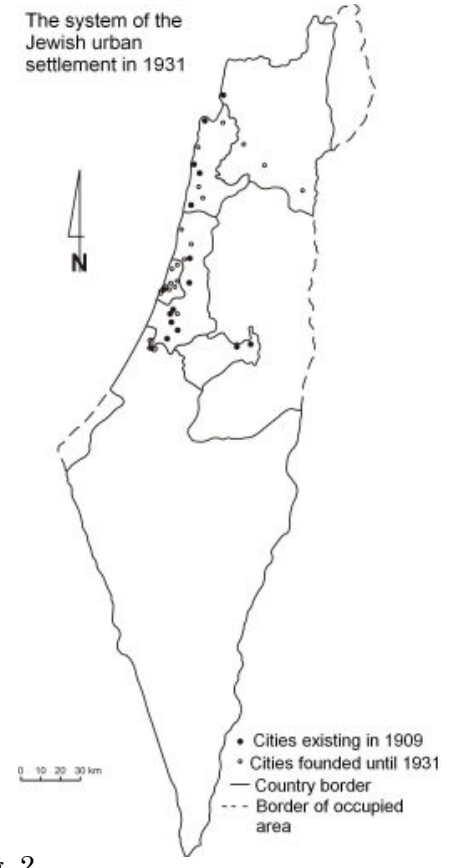

Fig. 2.

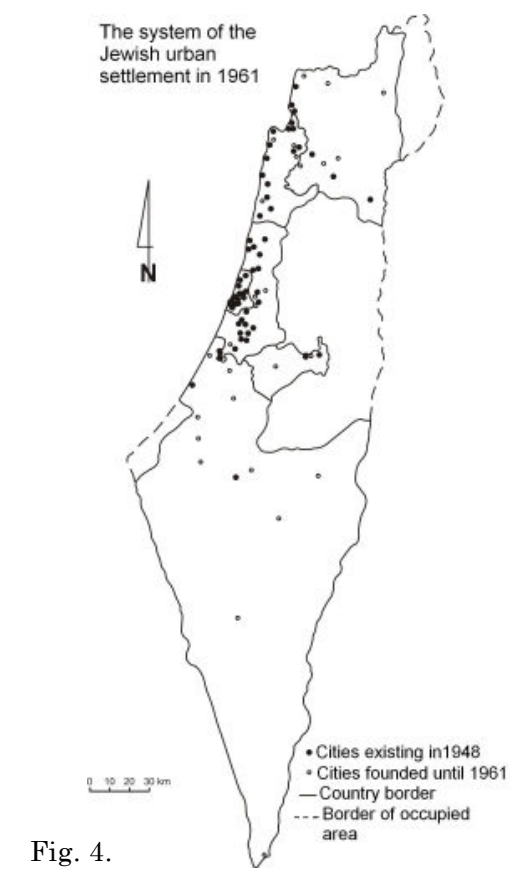

Source: Based on data: List of Localities, Their Population and Codes, Jerusalem, 1993. 
Table 3.

Number of newly founded Jewish settlement towns and cities in the region of Israel in the years 1909-1992

\begin{tabular}{|c|c|}
\hline Years & $\begin{array}{c}\text { Number of newly founded } \\
\text { Jewish settlement towns }\end{array}$ \\
\hline $1909-1931$ & 19 \\
$1931-1948$ & 22 \\
$1948-1961$ & 29 \\
$1961-1971$ & 2 \\
$1971-1981$ & 7 \\
$1981-1992$ & 5 \\
\hline
\end{tabular}

Source: Based on data: List of Localities, Their Population and Codes, Jerusalem, 1993.

The period 1961-1971 was, above all, the time of development of previously founded cities: only two new cities were founded (Table 3, Fig. 5). This situation was possible due to the policy, carried on since 1948, of building the so-called development cities, ready to receive a large number of inhabitants; due to that only a small fraction of the population moved to the new settlements.

More dynamic growth of the number of cities was noticed again in the years 1971-1981 (Table 3, Fig. 6). This occurred due to the development of Jewish settlements on the occupied regions of the Golan Heights (one city) and the East Bank of the Jordan River (six cities). By 1992, another five cities were founded there (Table 3, Fig. 5).

The analysis was conducted for the period ending in 1992. One can conclude that by then a network of Jewish settlements in Israel was formed. Its further developement was caused mainly by the influx of settlers to the already existing cities and estates as well as in the result of establishing them in the occupied regions. Changes in urban network of settlement in Israel which has taken place due to the enormous influx of imigrants from countries of former Soviet Union, who came to Israel in the last decade of $20^{\text {th }}$ century has not been taken under consideration in the work. Further anlysis was also hindered by the inaccessibility to the statistical data distinguishing Arab and Jewish towns in Israel.

In 1960s and 1970s the founding and developing of new towns in Southern District was part of a governmental plan of urbanisation growth prepared to achieving one of the main goals, that is, population scattering and desert management.

The adaptation of the desert regions was the dream of many Zionist leaders. Zionist movements regarded agriculture as the basis of the development of Israel. At first, however, the necessity of admitting still new, large immigrant waves required settling them in urban centres rather than in rural 
settlements because of shortage of water and of fertile soil in the Negev Desert. In addition, most immigrants came from cities. Because of the lack of large urban agglomerations, in the Southern District it was decided to develop a network of medium-size towns connected with agricultural settlements: it was a compromise between ideology and reality. Originally, state policy was conducted based on theory of central places, which didn't bring the expected results (Gradus, Stern, 1980).

The analysis of the differentiation of the growth rate of the number of cities in Israel allows stating that the development of the Jewish urban settlement pattern can be described by means of the model of innovation diffusion. It is easy to see that this model corresponds to the development stages of a settlement pattern suggested by Hudson (1969) who described the process of settlement diffusion using the cycle of innovation diffusion suggested by Hägerstrand (1967). The author distinguished three phases:

1. Colonisation, in which settlement propagates on a territory situated outside its original range or in still unoccupied areas of the territory.

2. Actual dispersion (density increase) of settlements connected with the growth in intensity of the settlement of the territory and with the filling up the gaps from the previous phase; the range of the settlement remains the same.

3. Competition, in which weaker elements are driven out and a regular patter of settlements is formed and stabilisation occurs.

In the first phase the growth of the number of inhabitants was accompanied by the growth in the number of cities. Jewish urban settlement embraced new, not yet colonised places. In Israel this phase lasted until the early 1960s. During the second and third aliyah, 19 cities were founded in the period 1909-1931. From 1931 until 1961 the population of Israel increased by about 1.5 million immigrants who settled down mostly in the 51 newly founded cities (Table 3). In this way, a settlement pattern with dynamic increase of range developed.

The filling stage started in the early 1960s. By the year 1971, despite of the continual influx of immigrants, only two new cities were founded (Table 3). The range of the urban settlement pattern did not change essentially despite of the increase in the number of inhabitants and of the increase of the urbanisation coefficient. The development of this stage was disrupted after 1967, when the Israeli army occupied the Golan Heights, West Bank and the Gaza Strip. The colonisation stage began again in these regions. From 1971 through 1992 twelve new Jewish cities were founded there (Table 3). In the remaining regions the filling stage continued: between 1971 and 1981 only two new cities were founded. In the period 1981-1992, as a result of a huge immigration wave (in 1990-1994 as many as 610000 immigrants came to Israel; Israel Statistical, 1995), the settlement network increased its range again and five new cities were founded, not taking into account the occupied territories.

In the areas where colonisation started earliest (districts: Tel Aviv, Jerusalem, Haifa) the urbanisation coefficient significantly exceeded 90\% (Tel Aviv: 

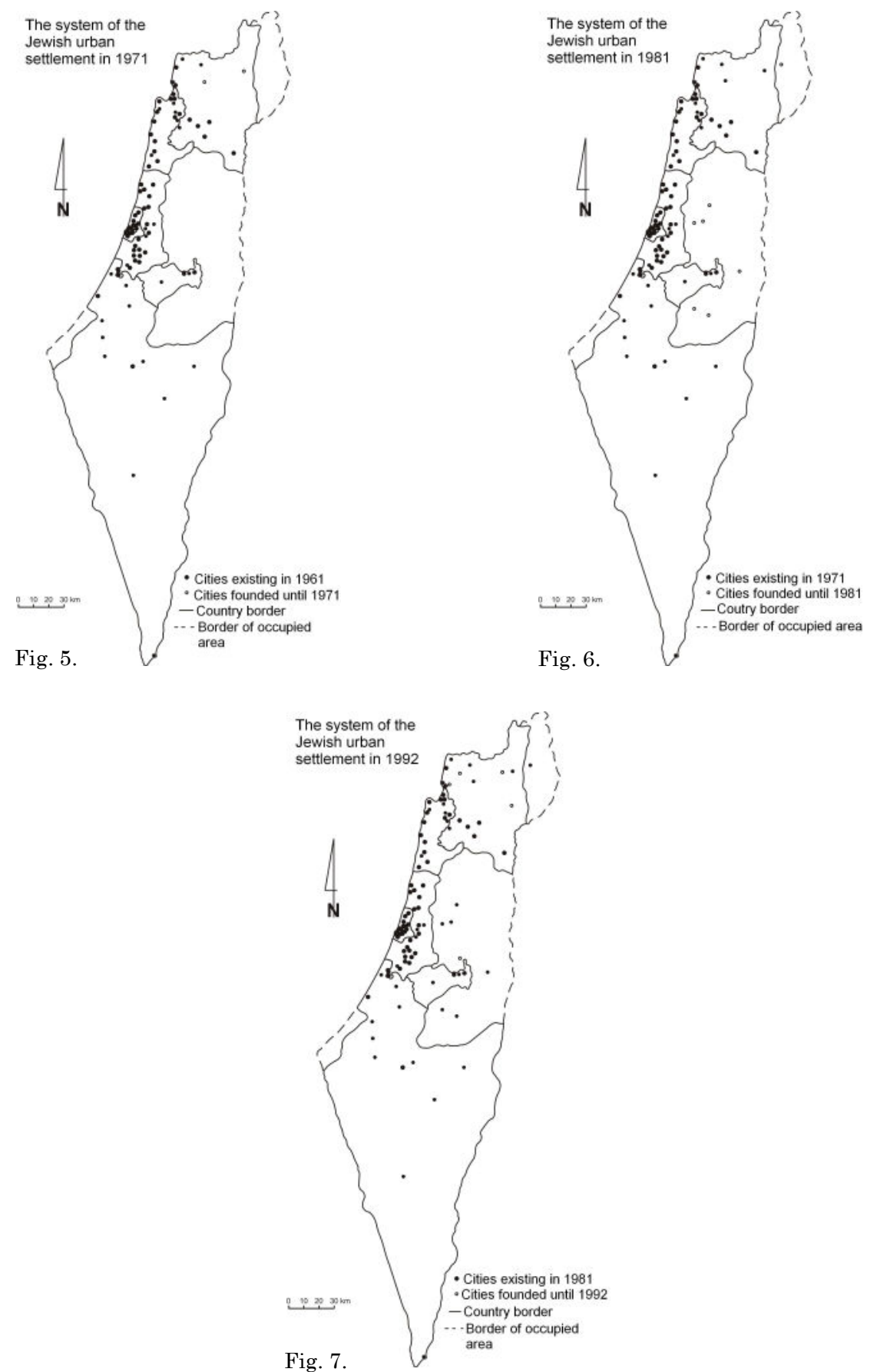

Source: Based on data: List of Localities, Their Population and Codes, Jerusalem, 1993. 
99.5\%, Jerusalem: 96.10\%), which means that the cities in question entered the competition phase.

Assuming that the theory of innovation diffusion is appropriate for the description of the development of the urban settlement pattern in the areas in question, one should consider the issue of the directions of the impulses sent by the innovation sources. An analysis of the maps of the Jewish urban settlements on the territory of Israel shows that originally (until 1948) cities were developing in two strips:

- Along the coastal plains,

- Along the Carmel Heights, in the fertile valley of Jezreel.

In the later period, most cities were founded in the same strips.

This may be evidence that innovations had definite directional tendencies. These directions may be determined theoretically on the basis of the theory of the settlement development in corridors, presented in details by C.F.J. Whebell (1969; Malisz, 1981). The following statements constitute the basis of his theory:

- The surface of the Earth is strongly differentiated both physically and economically.

- Innovations do not occur simultaneously in large areas, but propagate from one or a few points.

- Propagation occurs in accordance with the theory of smallest effort.

To move information and merchandise between the original points, communication paths are created with as little effort as possible. Corridors (strips, channels) develop along the paths; such corridors are capable of propagation of innovation impulses. It is in such corridors that cities can be founded and developed with the smallest expenses. For the existing strips to satisfy the postulate of the minimal cost, one has to take into account the physical differentiation of the surface of the Earth. Strips develop usually in privileged directions: along mountain valleys, coastal zones, banks of large rivers, etc. Strips, both in the process of creation and of developing, can be of first or second order. First-order strips connect the original points along the line of the smallest cost (Malisz, 1971). In the case of Israel the two oldest harbours, Tel Aviv and Haifa, can be regarded as the original points. They are connected by a "communication bundle".

Maps of communication in the analysed regions and maps of surface relief constituted the basis for the determination of the development corridors until 1948. A first-order strip was designated along the railway built at the beginning of the $20^{\text {th }}$ century and connecting Tel Aviv with Haifa; a secondorder strip was designated along the same railway from Haifa to Bet Shan and Akka as well as from Tel Aviv to Jerusalem. After 1948 new communication routes were built; their purpose was, a.o., to spur the development of the urban settlement network in the interior (Gradus, Stern, 1980). This caused the creation of a new development corridor from Tel Aviv to Jerusalem along a modernised and developed road joining the two cities. The importance of this corridor was confirmed by the establishment in Ramla of 
the capital city of the Central District (a city in the corridor). The railway Tel Aviv - Haifa lost its importance. The road running along the coast from Tel Aviv to Haifa and opened in 1947 achieved greater importance for the propagation of city creation impulses. This way, after the gaining of independence, thanks to the construction of roads, the course of the first-order strips was modified. First-order strips from before 1948 became now secondorder strips.

Analysis of the directions of diffusion of the Jewish urban settlement in Israel shows that except for the Negev Desert, most of the newly created cities, both before 1948 and after the gaining of independence, are localised in designated zones.

On the basis of the discussion above one can surmise that originally the decisive factors in the development of the Jewish settlement network were the following: surface relief, climate, soils, distance from the sea, distance from the existing cities. In the second stage one should add to these factors also political elements. Observation of the subsequent stages of the development of the Jewish settlements allows for hypothesising that the development follows the model of the innovation diffusion and that the innovation impulses propagate in accordance with the theory of the corridor development of the settlement networks.

To verify the hypotheses dealing with the factors influencing the directions of the spatial development of the Jewish urban settlements a dynamical (synchronous-comparative) model of the diffusion process has been built using the Monte Carlo method. This method allows checking in a simple way the action of a large number of variables on the entire system.

The first step in the spatial simulation consisted in building a matrix of the mean information field (MIF) which on the one hand is a probabilistic model of the distribution and on the other hand, a graphic description of the Monte Carlo method for the random sampling (Łoboda, 1983).

For this purpose, the investigated area of Israel has been divided into 442 squares of similar size (about 48 square $\mathrm{km}$ ). All squares with at least $50 \%$ of surface located on the area under investigation were admitted for the research project. Squares in which over $50 \%$ of the area consists of the sea or of the territory of another state have been eliminated.

Next, the probability of the localisation of the urban settlement units in each square was determined. For this purpose the factors that might influence the formation of the urban settlements network in Israel, have been determined on the basis of the analysis of the development of this network. These factors follow from the barrier effect, mostly connected with natural barriers, which may impede the diffusion of the cities (Maik, Parysek, 1978; Łoboda, 1983):

- Surface relief

- Soils

- Precipitation

- Natural mineral resources 
factors connected with the existence of sources of innovation diffusion:

- Distance from the sea (where the diffusion starts),

- Existence of old urban centres (up to 1948),

- Existence of the capital cities of districts (after 1948);

as well as factors taking into account the existence of the "diffusion channels":

- Existence of railway lines (until 1948),

- Existence of highways (after 1948).

All factors have been analysed and accorded appropriate rank.

Apart from the factors listed above one more element exists: the barrier effect. This hard to describe effect results from the presence, mostly in the Northern District, of the Arab settlement network. Unfortunately, it has to be omitted. Undoubtedly, the development of the Jewish urban settlement network is influenced also by traditions as well as historical, social, political and strategic conditions, which are difficult to include in the model. For this reason our method doesn't fully explain the diffusion of the Jewish cities in Israel.

Each of the squares underwent an analysis taking into account the factors listed above, form the point of view of the probability of the occurrence of the Jewish urban settlement units there. Analysis and preparation of the input information for the machine calculations became a concise description of the system under investigation.

The next step was the preparation of the input for the numerical simula- tion (creation of the observation matrix).

- Input I: takes into account only natural factors. In designated fields values related to relief, soils, precipitation and natural resources have been summarised.

- Input II: takes into account natural factors and distance from the sea.

- Input III: takes into account sources and channels of diffusion for the year 1909.

- Input IV: takes into account sources and channels of diffusion for the year 1948.

- Input V: takes into account natural factors and diffusion sources for the year 1909 .

- Input VI: takes into account natural factors and diffusion sources for the year 1948.

- Input VII: takes into account natural factors, sources and channels of diffusion for the year 1909 .

- Input VIII: takes into account natural factors, sources and channels of diffusion for the year 1948 .

- Input IX: takes into account natural factors, distance from the sea, sources and channels of diffusion for the year 1909.

- Input X: takes into account natural factors, distance from the sea, sources and channels of diffusion for the year 1948.

The creation of the observation matrix for ten input states was the basis for random sampling and for building ten simulation models of the development of the Jewish urban settlement network. 
The next steps were: transformation of the observation matrix into the matrix of mean information fields (MIF) and then into a matrix of probabilities, and sampling using the Monte Carlo method.

These steps have been achieved by means of a random number generator with uniform distribution.

The purpose of this statistical experiment was the generation of a sequence of random numbers originating from the fields created earlier. These numbers allowed for building theoretical models of the development of the Jewish urban settlement in Israel taking into account the factors described.

The next step in the procedure was the representation of the actual state of urban settlement according to the designated fields for the years 1948, 1967 and 1992.

Next, a verification of the simulated models of the Jewish urban settlements in Israel has been performed. This was an issue of the verification of non-parametric null hypotheses which state that an $n$-element random sample comes from a general set in which a stochastic independence of the random variables $\mathrm{X}$ and $\mathrm{Y}$ occurs.

If a statically significant correlation between the investigated variables for the determination of the correlation strength was observed, the Chuprov convergence coefficient, derived from the chi-square statistics, was applied (Luszniewicz, 1987).

Analyses and procedures verifying the model pattern of the cities of the Jewish settlement in the region of Israel in 1948, 1967 and 1992 showed that the best stochastic correspondence between the model (which takes into account elements of the theory of innovation diffusion) and the actual localisation of the cities of the Jewish settlement occurs in the years 1948 and 1967. This time corresponds to the colonisation stage as described in the theory of innovation diffusion. At that time, the range of the Jewish urban settlement expanded quickly, thus sources and channels of innovation diffusion played an important role, as did natural barriers and distance from the sea. Weaker correspondence between the theoretical and actual localisation of the cities of the Jewish settlement occurred after 1967, when the stage of the density increase of the network was ending and the stage of competition between the cities was starting. At that stage, natural barriers, distance from the sea as well as sources and channels of diffusion lost much of its importance, because the network development progressed mostly through the expansion of the already existing units of urban settlements.

Despite of the statistical verification of the hypotheses, the magnitude of the indices obtained allows for the hypothesis that apart from the factors analysed, influencing the development of the urban network of the Jewish settlement, other variables, not taken into account in the model, significantly affect the development.

An important factor hindering the propagation of the Jewish urban settlement in the region of Israel but not taken into account in this paper is undoubtedly the previously existing network of Arab settlement. Its 
influence is probably particularly large in upper Galilee, which is inhabited by a large Arab population. Security conditions in the territories being settled can be also important. Political decisions also influence the development of the urban network of Jewish settlement. Their importance was greatest in the early stage of the colonisation. They were not always in agreement with the expectation of the people, due to which they didn't always bring the expected results. Later, starting with 1960s, such decisions were made not intuitively, but on the basis of analyses of scientific theories, which were taken into account in the model. Factors resulting from the cultural diversity of the population arriving to Israel are difficult for grasp. The existence, after 1967, of the so-called Occupied Territories, nowadays partly transformed into the Palestine Autonomy was an important factor hindering the development of the Jewish urban settlement. In the first years after 1967 many Jewish settlers expected that these regions would be soon annexed by Israel; new Jewish settlements were founded there. Incorporating the variables listed above in the simulation model constructed in our study would be very difficult, but it would reflect better the reality.

\section{REFERENCES}

Domański R., 1995, Zasady geografii spoteczno-ekonomicznej [Principles of Socio-economic Geography; in Polish], PWN, Poznań, Warszawa.

CBS, Jerusalem, 2003, http://www.cbs.gov.il/population/new2003/

Gradus Y., Stern E., 1980, Changing Strategies of Development Toward a Regiopolis in the Negev Desert, Journal of the American Planning Association 46 (4).

Hägerstrand T., 1967, On Monte Carlo Simulation of Diffusion, [in:] W.L. Garrison, B.F. Marble (eds.), Quantitative Geography I, Studies in Geography, 13, Department of Geography, Northwestern University, Evanston, IL.

Hudson J.C., 1969, Diffusion in a Central Place System, Geographical Analysis 1, 1.

Israel - Districts, Subdistricts and Natural Regions, 1993, Technical Publications Series 62, Central Bureau of Statistics in Jerusalem.

List of Localities, Their Population and Codes, 31.XII.1992, 1993: Technical Publications Series 62, Central Bureau of Statistics in Jerusalem.

Luszniewicz A., 1987, Statystyka ogólna [General Statistics; in Polish], PWE, Warszawa.

Łoboda J., 1983, Rozwój koncepcji i modeli przestrzennej dyfuzji innowacji [Development of Conceptions and Models of Spatial Innovation Diffusion; in Polish], Acta Universitatis Wratislaviensis 585, Studia Geograficzne 37, Wrocław.

Maik W., Parysek J., 1978, Klasyfikacja i charakterystyka barier wzrostu w gospodarce przestrzennej [Classification and Characteristics of the Growth Bariers in Spatial Economy; in Polish], Biuletyn KPZK PAN 99, Warszawa.

Malisz B., 1971, Prognoza zmiany sieci osadniczej w Polsce [A Prognosis of the Change of the Settlement Network in Poland; in Polish], [in:] Polska 2000. Prognozy rozwoju sieci osadniczej [Poland 2000. Prognoses of the Development of the Settlement Network; in Polish], Ossolineum, Wrocław-Warszawa.

Malis z B., 1981, Zarys teorii ksztattowania uktadów osadniczych [An Outline of the Theory of the Formation of the Settlement Systems; in Polish], 2nd ed., Arkady, Warszawa.

Whebell C.F.J., 1969, Corridors: A Theory of Urban System, Annals of the Association of American Geographers 58.

English translation: Matgorzata Mikulska 